$1-1-1998$

\title{
A Nineteenth Century Habeas Corpus Mill: The Chinese Before the Federal Courts in California
}

Christian G. Fritz

University of New Mexico - School of Law

Follow this and additional works at: https://digitalrepository.unm.edu/law_facultyscholarship

Part of the Law Commons

\section{Recommended Citation}

Christian G. Fritz, A Nineteenth Century Habeas Corpus Mill: The Chinese Before the Federal Courts in California, 32 American Journal of Legal History 347 (1998).

Available at: https://digitalrepository.unm.edu/law_facultyscholarship/619

This Article is brought to you for free and open access by the UNM School of Law at UNM Digital Repository. It has been accepted for inclusion in Faculty Scholarship by an authorized administrator of UNM Digital Repository. For more information, please contact amywinter@unm.edu, Isloane@salud.unm.edu, sarahrk@unm.edu.

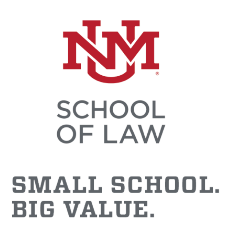

BIG VALUE. 


\title{
A Nineteenth Century "Habeas Corpus Mill": The Chinese Before the Federal Courts in California
}

\author{
by Christian G. Fritz*
}

Law has long been acknowledged as central to the Chinese experience in nineteenth century America, but legal historians have only recently shown a revived interest in this subject. Most of this renewed interest has focused on the experience of the Chinese before the courts and their efforts as a beleaguered minority to secure judicial protection from the discrimination they faced. Nonetheless, relatively little attention has been given to the many thousands of habeas corpus cases brought by the Chinese after 1882 in California's federal courts. ${ }^{1}$

In preventing the landing of Chinese ship passengers arriving in San Francisco in the late nineteenth century, federal officials triggered a series of challenges that would preoccupy California's federal courts for nearly a decade. This litigation produced overwhelming docket pressures, created an acrimonious breach within the judicial circuit, and brought the local federal judges under harsh public criticism for frustrating the demands of the anti-Chinese movement. Despite such pressures, San Francisco's federal judges sought to hear Chinese habeas corpus cases with judicial fairness and offered-for a time at least-protection from some of the most virulent opponents of the Chinese. A series of laws restricting Chinese

* Assistant Professor, The University of New Mexico School of Law, Albuquerque, N.M.

1. See, e.g., Sandmeyer, California Anti-Chinese Legislation and the Federal Courts: A Study in Federal Relations, 5 PaC. Hist. Rev. 189-211 (1936); M.R. Konvitz, The Alien and the Asiatic in American Law (1946); Wunder, The Chinese and the Courts in the Pacific Northwest: Justice Denied?, 52 PAC. HISt. Rev. 191-211 (1983); McClain, Jr., The Chinese Struggle for Civil Rights in Nineteenth Century America: The First Phase, 18501870, 72 CAL. L. Rev. 529-68 (1984); McClain, Jr., The Chinese Struggle for Civil Rights in 19th Century America: The Unusual Case of Baldwin v. Franks, 3 Law \& Hist. Rev. 349-373 (1985).

Two notable exceptions that discuss the writ litigation are Hudson N. Janisch, The Chinese, The Courts and The Constitution: A Study of the Legal Issues Raised By Chinese Immigration to the United States, 1850-1902, (J.S.D. dissertation, University of Chicago, 1971) and Nelson G. Dong, The Chinese and the Anti-Chinese Movement: The Judicial Response in California, 1850-1886 (seminar paper, Yale Law School, 1974). 
immigration, beginning in 1882, served as an immediate cause of disputes over the validity of detaining Chinese petitioners. Two judges in particular, Ogden Hoffman of the Northern District of California, and Lorenzo Sawyer, the state's presiding circuit judge, played prominent roles in this habeas corpus litigation.

As early as September 1883, San Francisco newspapers referred to Hoffman's court as "the habeas corpus mill," and the federal judges themselves soon adopted the nickname. ${ }^{2}$ Running these "mills" took its physical toll, and both Hoffman and Sawyer were assisted from time to time by Nevada's federal district court judge, George M. Sabine. As Hoffman's court was the only federal district court for all of California between 1866 and 1886, California's southern district judge could only offer belated assistance. Moreover, Oregon's federal district judge, Matthew P. Deady, only occasionally traveled to San Francisco to hold a term of Sawyer's circuit court. In addition to hearing most of the ordinary federal judicial business for Oregon, Deady had his own, albeit much smaller, share of Chinese habeas corpus cases to attend to and thus played a minimal role in the Chinese cases arising in California's northern district. ${ }^{3}$ As a result, the task of hearing the many thousands of Chinese writ petitions fell primarily on Hoffman and Sawyer. Indeed, between 1882 and 1890, Hoffman's court alone heard over seven thousand Chinese habeas corpus cases. The result of this extraordinary caseload left the district and circuit courts with little time to conduct ordinary judicial business. ${ }^{4}$

Although California's highest ranking federal judge, United States Supreme Court Justice Stephen J. Field, played a minor role in the day-today adjudication of the thousands of writ cases, he assumed a major role in presiding over several of the dozens of habeas corpus test cases. When Field came to California to hold the circuit court, he was often joined by not only Sawyer, but also Hoffman and Sabine. ${ }^{5}$ He then presided over the

2. San Francisco Alta California. Sept. 16, 1882; Lorenzo Sawyer to Matthew P. Deady, Feb. 18 and Oct. 13, 1884 (Matthew P. Deady Papers, Oregon Historical Society).

3. Ralph James Mooney, in Matthew Deady and the Federal Judicial Response to Racism in the Early West, 63 Or. L. Rev. 561 (1984), discusses Deady's Chinese cases. Moreover, from the beginning of Deady's judgeship in 1859 and throughout the 1880 s he heard both district and circuit matters in Oregon with only occasional help from Justice Stephen J. Field (after 1863) and Circuit Judge Lorenzo Sawyer (after 1869). See Minutes, United States District Court, District of Oregon, Sept. 12, 1859 to July 1, 1893, RG 21, NA.

4. Between June 27, 1882 and December 1, 1890, the Chinese filed 7,080 habeas corpus petitions in Hoffman's admiralty docket. During the same period only 398 cases were filed that were, strictly speaking, admiralty matters.

See Admiralty (Private) Casefiles, passim [2499-10,155].

5. An Act of June 1, 1872, 17 stat. 196, provided that whenever a difference of opinion existed among judges sitting as a circuit court "the opinion of the presiding justice or presiding judge shall prevail, and be considered the opinion of the court for the time being" but upon proper certification the case could then be taken to the Supreme Court upon a writ of error or an appeal. See id., section 1. 
court and cast the decisive opinion, even though this dominance, stemming from his status as the circuit justice, was disproportionate to his labors in the actual adjudication of these hearings. His willingness to dismiss the experience and insights of his fellow judges who were toiling "in the mill" did not contribute to judicial collegiality. Apart from Field's brusque manner of assuming control, the local federal judges, Hoffman and Sawyer especially, were given inconsistent legal guidance by Field and made to feel as though they were incompetent. While the trial judges were ultimately vindicated by the Supreme Court, with Field vigorously dissenting, the divisions within the circuit remained and were part of a larger issue of conflicting judicial style and personality.

As the presiding judge of the circuit, Field might have inculcated a more harmonious atmosphere, but his domineering, even vindictive approach antagonized his fellow West Coast judges and constituted a divisive element. Undeniably brilliant, Field's inability to suffer opposition, the certainty of his convictions, and his often ruthless conduct in promoting his objectives brought him into conflict with those around him. ${ }^{6}$ Indeed, Field's autobiography supports the picture of a man continually involved in controversies and feuds from his earliest days in California. In 1884, Field admitted in a personal letter that in his visits as circuit justice to California, he had "generally succeeded in stirring up a greát deal of feeling, mingled with much personal bitterness towards myself." 7

The judicial dispute between Field on the one hand and Sawyer and Hoffman on the other essentially concerned the protections granted the Chinese under the treaty with China. Despite pressure from federal officials, the press, and the public, Hoffman and Sawyer believed that their judicial duty required them to interpret the Restriction Acts in light of the treaty with China. In so doing, they insisted that the detained Chinese have access to the courts to bring writs of habeas corpus, and that they be given the opportunity to establish their right to enter the country. While Field concurred in this liberal position in one of the first major test cases, he later reversed himself and placed himself at odds with Sawyer and Hoffman. The local federal judges simply could not justify excluding Chinese from the country in the absence of any opportunity to establish their right to enter.

Ironically, the role of benefactor to the Chinese cause was one that neither Hoffman nor Sawyer had sought or wanted. In fact, a distinct ambivalence existed in the minds of the judges about their role in this process. Hoffman, in particular, consistently discharged the Chinese who

6. For an example of Field's dynamic personality, see Fritz, Politics and the Courts: The Struggle Over Land in San Francisco, 1846-1866, 26 Santa Clara L. Rev. 127-164 (1986).

7. Stephen J. Field to Matthew P. Deady, May 15, 1884, Matthew P. Deady Papers, Oregon Historical Society. See also, Stephen J. Field, Personal Reminiscences of Early Days in California With Other Sketches (privately printed, 1880). 
petitioned his court on writs of habeas corpus and allowed them into the country. While doing so, Hoffman held strong negative views about Chinese immigration, many of which he tempered or consciously suppressed as being incompatible with his judicial duty.

The difference between what Hoffman said and did about the Chinese appearing before him suggests the equivocal position they occupied before the federal courts. Along with most white Californians-including most of the lawyers representing the Chinese and the other federal judges serving the Far West-Hoffman favored the restriction of Chinese immigration and regarded the Chinese as racial inferiors. Nonetheless, his court gave thousands of Chinese the chance to convince him on an individual basis that they were entitled to freely enter the country. Ultimately, Hoffman's commitment to legal procedure and judicial process, the burdens of proof, weight of evidence, and allegiance to a hierarchy of sources of law accounted for the considerable protection and favorable decisions the Chinese encountered in the northern district. ${ }^{8}$

Although kindred spirits in the disposition of the habeas corpus cases, Hoffman and Sawyer had substantial differences. While Sawyer was born on a New York farm and trekked across the plains to California with the advent of the Gold Rush, Hoffman grew up accustomed to the luxuries of living in New York City, and arrived in San Francisco aboard a Pacific Mail Steamship. ${ }^{9}$ While Sawyer quickly developed support and political prominence in California's Republican party, Hoffman was less successful in creating a political base within that same party, and only narrowly received his judgeship after relying heavily upon his New York political connections. ${ }^{10}$ Nonetheless, both Hoffman and Sawyer were staunch Republicans who might have been expected to favor free immigration as a source of cheap labor. While the Republican party in California had initially welcomed the arrival of the Chinese for these reasons, by the time Hoffman and Sawyer came to hear the flood of Chinese habeas corpus cases in the mid-1880s, great public opposition had developed to Chinese immi-

8. Ironically, Hoffman had a far greater positive impact upon the Chinese in San Francisco than did his counter-part for the district of Oregon who apparently viewed the Chinese more sympathetically. See Mooney, Matthew Deady and the Federal Judicial Response to Racism in the Early West, 63 Or. L. REv. 561-637 (1984). Mooney indicates that in slightly over eight years (1885 through early 1893) Judge Deady discharged at least 150 Chinese by habeas corpus petitions. See id. at 629 , note 266. By comparison, Hoffman released 533 Chinese in slightly over two years between October 1, 1888 and December 1, 1890. Moreover, between 1882 and 1890 over 7,000 Chinese habeas corpus petitions were filed in Hoffman's court.

9. On Sawyer, see L. Sawyer, Way Sketches; Containing Incidents of Travel. Across the Plains From St. Joseph to California in 1850, (1926). On Hoffman, see O.T. Shuck, A History of the Bench and Bar of California 472.73 (1901).

10. For the context of Hoffman's difficulty in securing his appointment, see Hall, Mere Party and the Magic Mirror: California's First Lower Federal Judicial Appointments, 33 Hastings L.J. $819-837$ (1981). 
gration. By that time, both the Democratic and Republican parties in California had taken up the cause of Chinese exclusion. " Thus, one must look to the dynamics of the judicial process and Hoffman's and Sawyer's conception of judicial duty in order to discover what motivated them in taking an extremely unpopular stand.

Long before the passage of the Chinese Restriction Act of 1882, the Chinese had become a beleaguered minority. Early discrimination seemed more racially than economically motivated, but by the 1870 s, the complaints about Chinese competition merged negative racial stereotypes with an effort to end Chinese immigration and discourage those present from remaining. ${ }^{12}$ Although California spearheaded the movement for exclusion, the sources of anti-Chinese sentiment had national origins. Both in terms of the political expediency of exclusion and the prejudice that underlay the anti-Chinese movement, California found significant support from other sections of the nation. ${ }^{13}$ Nonetheless, the dominant role California played in the anti-Chinese movement has obscured the significance of the Restriction Act of 1882 as an important departure in the history of American immigration. For the first time in the nation's history an immigrant group would be excluded on the basis of race. ${ }^{14}$

Those seeking restriction of Chinese immigration and presence in California confronted their greatest obstacle in the form of the Burlingame Treaty of 1868 between China and the United States. ${ }^{15}$ Article five of the treaty provided for the reciprocal recognition of "the inherent and inalienable right of man to change his home and allegiance" and the "mutual advantage of the free migration and emigration" of people of both nations "for purposes of curiosity, of trade, or as permanent residents." 16

Article six guaranteed Chinese subjects visiting or residing in the United States "the same privileges, immunities, and exemptions in respect to travel or residence as may there be enjoyed by the citizens or subjects of the most favored nation." 17

As the treaty clearly invited Chinese immigration, federal courts invalidated state measures to impose limitations on such immigration. ${ }^{18}$

11. A. Saxton, The Indispensable Enemy, Labor and the Anti-Chinese Movement in California (1971); S.C. Miller, The Unwelcome Immigrant: The American Image of the Chinese, 1785-1882 (1969); M.R. CoOlidge, Chinese Immigration (1909).

12. Miller, supra note 11; Coolidge, supra note 11; E. C. Sandmeyer, The AntiChinese Movement in California (1939).

13. MILLER, supra note 11 ; SAXTON, supra note 11.

14. E.P. Hutchinson, Legislative History of American Immigration Policy, 17981965 (1981).

15. July $28,1868,16$ Stat. 739.

16. Id.

17. Id.

18. See, e.g., In re Ah Fong, 1 F. Cas. 213 (C.C.Ca. 1874) (No. 102). 
Federal courts also interpreted the "most favored nation" article as implicitly promising the Chinese residents the right to work and earn a living in the United States. Moreover, they held that the Chinese could not be deprived of any "privileges, immunities, and exemptions" enjoyed by other foreigners in the country. ${ }^{19}$ Indeed, in almost every decision of California's federal courts dealing with the Chinese during the 1870's, the Burlingame Treaty played a central role. ${ }^{20}$

While judges who invalidated California's legislative and even constitutional efforts to exclude and discriminate against the Chinese made themselves highly unpopular, they suggested answers to the Chinese "problem." In 1874, for instance, Field presided over California's federal circuit court and in In Re Ah Fong struck down a state law that interfered with Chinese immigration. ${ }^{21}$ Field acknowledged and sympathized with the "general feeling" that "the dissimilarity in physical characteristics, in language, in manners, religion and habits, will always prevent any possible assimilation of them with our people." ${ }^{22}$ Chinese exclusion could be achieved, but Field advised that "recourse must be had to the Federal government, where the whole power over this subject lies." 23

Indeed, by 1880 the anti-Chinese forces had helped bring about the renegotiation of the Burlingame Treaty. ${ }^{24}$ The new treaty represented a compromise between the demands of the West Coast and deference to existing rights and considerations of trade and commerce with China. Article one permitted the United States "to regulate, limit or suspend" but not "absolutely prohibit" the immigration of Chinese laborers whenever, in the opinion of the United States, such laborers threatened or endangered the country's "interests" or "good order." 25 Such limitation or suspension, however, "shall be reasonable and shall apply only to Chinese who may go to the United States as laborers, other classes not being included in the limitations." 26 Moreover, the treaty pledged the United States to protect those Chinese residing in the country from "ill treatment at the hands of any other persons" and "to secure to them the same rights, privileges, immunities, and exemptions as may be enjoyed by the citizens or subjects of the most favored nation." 27

19. Baker v. City of Portland, 2 F. Cas. 472 (C.C.Ore. 1879) (No. 777); In re Parrot, 1 F. 481 (C.C.Ca. 1880); In re Quong Woo, 13 F. 229 (C.C.Ca. 1882).

20. Dong, supra note 1 , at 226-391.

21. In re Ah Fong, 1 F. Cas. 213 (C.C.Ca. 1874) (No. 102).

22. Id. at 217.

23. $l d$.

24. Treaty of November 17, 1880, 22 Stat. 826.

25. Id., art. 1.

26. $I d$.

27. Id., art. 3 . 
The first Restriction Act ("An Act to execute certain treaty stipulations relating to Chinese") that passed in 1882 suspended the immigration of all Chinese laborers for ten years, but did not apply to Chinese laborers already in the United States at the new treaty's conclusion on November 17, $1880 .{ }^{28}$ Chinese laborers were defined as "both skilled and unskilled laborers and Chinese employed in mining." 29 In order to allow Chinese laborers already in America by that date to come and go freely, the act set up an identification system. Before resident Chinese laborers could leave the United States, the collector of customs was to issue a so-called return certificate that included "all facts necessary for the identification of each of such Chinese laborers." ${ }^{30}$ Upon returning to the United States, the certificates issued to Chinese laborers were compared with a permanent identification record created at the time of the certificate's issuance. If satisfied that the Chinese laborer was entitled to land, since most would be travelling by ship, the collector would file and cancel the return certificate. Under the Act, Chinese laborers without legitimate return certificates were denied entry, and any Chinese unlawfully in the country

shall be caused to be removed therefrom to the country from whence he came, by direction of the President of the United States, and at the cost of the United States, after being brought before some justice, judge, or commissioner of court of the United States and found to be one not lawfully entitled to be or remain in the United States. ${ }^{31}$

Constrained by the terms of the 1880 treaty with China, the Act of 1882 sought to insure that Chinese merchants, diplomats, and other nonlaborers were, in fact, who they claimed to be. The Act required the Chinese government to issue descriptive certificates in English, attesting to the status of the holder. These so-called Canton certificates were to serve as prima facie evidence of the individual's right to enter the country. ${ }^{32}$ In essence, the Act was designed to exclude all Chinese laborers from immigrating to the United States. ${ }^{33}$ Proponents of the Act implicitly assumed, erroneously as events would show, that the law would effectively end Chinese traffic into the nation's ports.

Although the passage of the 1882 Act was widely hailed in California, its excessively rigid implementation by San Francisco's collector,

28. Act of May 6, 1882, 22 Stat. 58.

29. Id., section 15 .

30. Id., section 4 .

31. Id., section 12.

32. Id., section 6 .

33. By May 6, 1882, when the Act was passed, the only persons excluded from immigrating into the United States were women imported for the purposes of prostitution, convicts under non-political felony sentences, and all Chinese laborers. On the exclusion of convicts and prostitutes, see Act of March 3, 1875, 18 Stat. 477. 
ambiguities in the Act itself, and the readiness of the Chinese community to contest its implementation, quickly dispelled the popular hope that the Act would effectively end Chinese immigration. After years of hearing that authority over Chinese immigration rested with Congress, it is little wonder that the anti-Chinese forces placed such hopes on the law. The anti-Chinese movement, San Francisco customs officials, and the newspapers were unwilling to see the Act as a carefully defined and limited exception in the treaty with China and soon grew impatient with the Act's results. In the context of the 1880 treaty, the United States reaffirmed its obligation to protect all Chinese already in the country, or those who entered legitimately and to insure them most favored nation status. Those who tended to view Chinese indiscriminately as a problem, and who primarily sought to exclude as many Chinese as possible, lost this perspective.

San Francisco's collector, for one, made it clear that he intended to implement the Act as strictly as possible. In so doing, he triggered a large number of writs of habeas corpus to the district and circuit courts. Indeed, soon after the passage of the Act, the collector announced that he intended to exclude any Chinese who had neither a return certificate, nor a Canton certificate. This absolutist position led him to detain the first Chinese to arrive in San Francisco after the 1882 Act became law.

Notwithstanding the fact that Ah Sing, a cabin steward on the steamer Sydney, had lived in California since 1876, the collector refused him entry for lack of a return certificate. On a writ of habeas corpus to the circuit court, with Justice Field presiding, Ah Sing was discharged. ${ }^{34}$ Field made it clear that while he personally favored restriction, the Act had never been intended to apply to Ah Sing's situation. In any event, Field noted, since Ah Sing had remained on board the vessel throughout the voyage, he had never technically left United States territory.

Undeterred by Field's ruling, the collector proceeded to detain other Chinese sailors on the Sydney on the grounds that they had lost their claim of remaining continuously within the jurisdiction of the United States, on account of several hours of shore leave in Australia. Field again discharged the Chinese petitioners and showed his annoyance at the collector's strained interpretation of the Act. He warned that "absurd" applications of the Act might lead to its repeal. ${ }^{35}$ Instead, Field suggested that the "wisdom of its enactment will be better vindicated by a construction less repellent to our sense of justice and right." ${ }^{36}$ Nonetheless, Field had to repeat his admonition several months later in a case involving a Chinese merchant. ${ }^{37}$

The significance of In Re Low Yam Chow (1882) lay in its expression, both by Field and Hoffman, of the underlying purpose of the Restriction

34. In re Ah Sing, 13 F. 286 (C.C.Ca. 1882).

35. In re Ah Tie, 13 F. 291, 294 (C.C.Ca. 1882).

36. Id. at 295.

37. In re Low Yam Chow, 13 F. 605 (C.C.Ca. 1882). 
Act and the necessity of interpreting it in the context of the new treaty with China. The case involved a Chinese merchant who had done business in South America for many years but was affiliated with a Chinese mercantile firm in San Francisco. After the collector refused his landing in San Francisco in August 1882, Low Yam Chou sought a writ of habeas corpus from the circuit court which was composed of Field and Hoffman. Both judges argued that the objective of the treaty of 1880 had been to exclude only certain types of Chinese deemed to pose a threat to the United States.

The danger, Hoffman explained, lay in unrestricted immigration of Chinese laborers, "whose presence here in overwhelming numbers was felt by almost all thoughtful persons to bear with great severity upon our laboring classes, and to menace our interest, our safety, and even our civilization." ${ }^{38}$ Thus, the treaty and the Act were intended to halt undesirable Chinese immigration while still promoting the potentially great benefits of Chinese commerce. In a note to his opinion, Field went so far as to enumerate statistics of the enhanced trade with China since the signing of the Burlingame Treaty.

As the new treaty with China gave to all Chinese subjects already in the United States and to all those who immigrated, except laborers, most favored nation status, Field dismissed the claim that Low Yam Chow needed a Canton certificate to come ashore in San Francisco. Such certificates were not indispensable, Field held, but merely an aid to establishing merchant status, and in the absence of such a certificate, Low Yam Chow could introduce oral evidence to establish his right to enter. Requiring the petitioner to return to China to obtain a Canton certificate before entering the United States was "unreasonable," and opposed to the "Ietter and spirit" of the Restriction Act. ${ }^{39}$ Hoffman concurred with Field's holding, and spoke for both when he warned that the collector's overly narrow interpretation of the Act threatened to work its repeal. Even after the decision Hoffman continued to warn that "friends" of the Act were being counterproductive in pushing for an unreasonable construction that might bring the law into "odium and disrepute." 40

Despite the abuse he later received, there is little reason to question Hoffman's sincerity in wishing the law well. Several months after the Low Yam Chow case, Judge Deady of Oregon rendered a decision that largely followed the reasoning of Field and Hoffman. ${ }^{41}$ Deady held that a Chinese actor was not a "laborer" for the purposes of the Act and could establish his right to enter without a Canton certificate. Hoffman wrote to Deady expressing his agreement with the result, but wondered if Deady's definition

38. Id. at 615 .

39. Id. at 609 .

40. See San Francisco Alta California, Sept. 13, 1882.

41. In re Ho King, 14 F. 724 (D.Ore. 1883). 
of a laborer as "one that hires himself out or is hired out to do physical toil," opened "the door . . . to those classes whom the law intended to exclude." ${ }^{42}$ Hoffman pointed out that some Chinese laborers, like market gardeners, fishermen, and cigarmakers often worked as partners and not for wages. "Indeed, by forming cooperative associations the members to be paid by a share of the profits, they might in all cases take themselves out of the category of "laborers." ${ }^{43}$ As a result, Hoffman suggested that Deady might modify his opinion before publication in the official reports. Although Deady did not take Hoffman's advice, the exchange underscores Hoffman's commitment to the objectives of the Restriction Acts as long as they were accomplished in the light of the treaty with China. ${ }^{44}$

Beyond the significance of Field and Hoffman hearing their first Chinese habeas corpus case together, the decision in Low Yam Chow marked an agreement of opinion that was not repeated. ${ }^{45}$ Within two years, Field would recant his opinion and come close to repudiating the treaty with China in his eagerness to put an end to Chinese immigration. ${ }^{46}$ Hoffman, however, remained committed to interpreting the Restriction Acts within the context of "the solemn pledges of the treaty," despite judicial results he felt very defensive about and which earned him considerable abuse. ${ }^{47}$ Judges Sawyer and Sabine came to share Hoffman's conviction that the laws to implement the treaty were to be guided by the spirit and intention of that treaty. Although deeply hurt by newspaper attacks and occasionally responding with decisions that seemed to reflect public pressure, Hoffman never repudiated his opinion in the Low Yam Chow case. ${ }^{48}$ Although

42. Ogden Hoffman to Matthew P. Deady, Feb. I, 1883 (Deady Papers, OHS). For Deady's definition of a laborer, see In re Ho King, 14 F. 724, 725 (D.Ore. 1883).

43. Ogden Hoffman to Matthew P. Deady, Feb. 1, 1883 (Deady Papers, OHS).

44. Although he had competed against Hoffman for the circuit judgeship in 1869, and initially thought that the San Francisco judge had deliberately blocked his chances, Deady remained on good terms with Hoffman. Beyond Deady's forgiving nature, he and Hoffman were drawn together by their shared experiences and problems as federal trial judges. For nearly twenty years they commiserated about their low salaries and lobbied together to improve the financial security of district judges. See I Pharisee Among Philistines: The Diary of Judge Matthew P. Deady, 1871-1892 xxiii (M. Clark, Jr. ed. 1975); E. W. McGraw to Matthew P. Deady, Feb. 8, 1870, Ogden Hoffman to Deady, Dec. 1, 1868, Feb. 3, 1869, Dec. 13, 1876 and Nov. 26, 1883 (Deady Papers, OHS).

45. Following the Low Yam Chow case, Field rendered another opinion in In re Ah Lung, 18 F. 28 (C.C.Ca. 1883), before he returned to the east coast. While he interpreted the 1882 Restriction Act narrowly, he nonetheless emphasized its legislative history, directed at Chinese laborers only, and reiterated the need to interpret the Act in the context of the treaty with China.

46. See In re Cheen (sic) Heong, 21 F. 791, (C.C.Ca. 1884) and Field's dissent in Chew Heong v. United States, 112 U.S. 536 (1884).

47. In re Low Lam Chow, 13 F. 605, 617 (C.C.Ca. 1882).

48. See, e.g., In re Shong Toon, 21 F. 386 (D.C.D.Ca. 1884); In re Chin Ah Sooey, 21 F. 393 (D.C.D.Ca. 1884). 
sharing Field's view on the Chinese, Hoffman rejected Field's pragmatic, perhaps even unprincipled, approach to ending the flow of Chinese immigration.

After his early interpretation of the Restriction Act of 1882, Field left. for the East Coast, leaving Hoffman and Sawyer with the task of adjudicating the large numbers of habeas corpus cases that resulted from vessels arriving in San Francisco with Chinese passengers. Not only was Hoffman's "habeas corpus mill" kept busy by the collector's continuing refusal to let the Chinese land, but novel questions were presented that had not been anticipated by the Act itself.

In In Re Chin Ah On (1883), Hoffman addressed the question whether a Chinese laborer residing in California at the time the treaty with China was ratified, but who went to China before the passage of the Act, was entitled to reenter the country without a return certificate. ${ }^{49}$ Hoffman's decision revealed his commitment to interpret the Restriction Act in light of the treaty with China. Hoffman conceded that if the terms of the treaty and the Act were irreconcilably conflicting, his judicial duty would have been to obey the latest expression of legislative will. Since the Act only sought to restrict new Chinese laborers from coming into the United States, however, Hoffman considered Chin Ah On's situation simply a congressional oversight. As such, Hoffman sought guidance from the treaty. Article two guaranteed that Chinese laborers already in the country at the time of the treaty could freely leave and reenter the United States. Hoffman thus held that Chin Ah On could not be required to hold a return certificate as a condition of reentering the country.

Hoffman buttressed his reconciliation of the Act with the treaty by noting that the collector's superiors in Washington, D.C. had also concluded that Chinese laborers already in the country at the time of the treaty were entitled to reenter even if they lacked a return certificate. More importantly, Hoffman believed that to deny Chin Ah On the right to land "would be to attribute to the legislative branch of government a want of good faith and a disregard of solemn national engagements which, unless upon grounds which leave the court no alternative, it would be indecent to impute to it." 50

Thus, Hoffman voiced concerns that both Presidents Hayes and Arthur had raised about maintaining national honor by faithfully adhering to the treaties with China. To Hoffman, the importance of maintaining treaty obligations was linked to his sense of personal honor. The nation, no more than an honorable gentleman, would be loathe to break a solemn promise. Indeed, according to Hoffman, it was "indecent" to attribute such a motive to Congress unless the intention to break the treaty appeared unequivocally.

49. In re Chin Ah On, 18 F. 506 (D.C.D.Ca. 1883).

50. Id. at 507-08. 
As such, he felt bound and determined to keep the nation on an honorable course by interpreting the 1882 Act in the light of the renegotiated treaty with China two years earlier.

The practical result of Hoffman's decision in Chin Ah On was that any Chinese laborer without a return certificate could land in San Francisco after establishing his prior residence. Sawyer and Hoffman later established June 6,1882 , as the date after which all Chinese laborers who left California would not be allowed to reenter without a return certificate. ${ }^{51}$ That date marked the first availability of return certificates from the customs house in San Francisco. Although they established such exemptions as seemed dictated by the spirit of the treaty with China, Hoffman and Sawyer refused to accept any excuses by Chinese laborers for failing to present certificates unless they fell into exempted situations like that of Chin Ah On. ${ }^{52}$ Nonetheless, both the circuit and district courts found their dockets expanding with Chinese habeas corpus cases. Less concerned with judicial reasoning, the newspapers and the general public focused on the fact that the Chinese regularly entered San Francisco through writs granted by the courts.

The numbers of Chinese who came into Hoffman's court and succeeded in overtaxing the northern district resulted in large measure from Hoffman's commitment to judicial due process. By insisting that each Chinese person detained by the collector had a right to challenge his detention in a habeas corpus proceeding, Hoffman insured himself of a crowded docket. Moreover, in such hearings, the Chinese were entitled as a procedural right to present any evidence, written or oral, that might establish their unlawful confinement. Denial of access to his court or the right to testify and present evidence on their own behalf was a violation of basic rights to a fair trial implicitly guaranteed by the treaty of 1880 . The determination of whether Chinese were wrongfully denied liberty by the actions of the customs house officials was emphatically a matter for his court to decide. Hoffman proved unwilling to abdicate such responsibility regardless of the grief it caused him.

The sheer number of Chinese writ cases concerned Hoffman and his judicial colleagues, as well as the newspapers, because of their draining impact on the federal courts. In 1884 Hoffman delivered the opinionactually more of a commentary-in In Re Chow Goo Pooi, heard before the circuit court which was composed of Sawyer, Sabine, and Hoffman. ${ }^{53}$ The case at hand involved an attempt by the United States attorney to bypass Hoffman's consideration of Chow Goo Pooi's habeas corpus petition in the district court, by asking Sawyer, as the circuit court judge, to arrest the petitioner as an illegal alien. Speaking for a unanimous court,

51. In re Leong Yick Dew, 19 F. 490 (C.C.D.Ca. 1884).

52. See In re Tong Ah Chee, 23 F. 441 (D.C.D.Ca. 1883); In re Shong Toon, 21 F. 386 (D.C.D.Ca. 1884); In re Ah Kee, 2 I F. 701 (C.C.D.Ca. 1884); In re Kew Ock, 21 F. 789 (C.C.D.Ca. 1884)

53. In re Chow Goo Pooi, 25 F. 77 (C.C.D.Ca. 1884). 
Hoffman asserted the right of all Chinese detained by the collector to seek their liberty through a writ of habeas corpus, and the exclusive power of the courts to decide whether the petitioner was entitled to enter the country under the terms of the Restriction Act. Moreover, Hoffman noted the lack of judicial power, under the Act, to detain the vessels which brought Chinese to San Francisco, until the numerous investigations and adjudications pertinent to the right of such passengers to land were completed.

Hoffman then turned to what he regarded as the most important question raised under the Act: Given the flood of habeas corpus petitions, what was to be done with those Chinese passengers in the custody of the federal courts after the vessel that brought them had departed? Hoffman examined the "very vague and inexplicit" section of the Act which called for the deportation of Chinese ${ }^{54} \mathrm{He}$ concluded that the habeas corpus proceedings satisfied the requirements of determining if Chinese were illegal aliens, but that Chinese remanded to the custody of the marshal could only be held for a "reasonable time, to await the direction of the president." 55 Drawing an analogy with extradition laws, Hoffman argued that remanded Chinese could only be detained for two months after which they must be released in the absence of "just excuse." 56

Anticipating the public reaction to his opinion, Hoffman warned of the severe strain on the federal courts in San Francisco, and called for legislation to relieve the judges from habeas corpus cases. Observing that in his court alone nearly two hundred writ cases remained on the calendar, Hoffman explained that

[f]or five or six weeks, even with night sessions, I have been unable to make any great impression on them. All ordinary business, public and private, of the court is necessarily suspended, or if resumed, these passengers, many of whom may be entitled to their discharge, are left either in custody or on bail awaiting the determination of their cases. ${ }^{57}$

Hoffman called on Congress to establish a special commissioner who would have final authority to resolve the claims of Chinese passengers. Hoffman's exhaustion from overwork made far less of an impression than the fact that Chinese were walking out of his courtroom and into the streets of San Francisco. Moreover, Hoffman's reputation suffered by comparison with the strong anti-Chinese position of the collector. Customs house officials were depicted as "striving hard" to prevent frauds and the landing of "bogus coolies," but found themselves opposed by "every Chinaman in the city, the Chinese Consulate, dozens of purchased lawyers and untoward circumstances enough to make them sicken of their task." 58 On the other

54. 1d. at 79. See the Act of July 5, 1884, 23 Stat. 115, section 12 .

55. In re Chow Goo Pooi, 25 F. 77, 81.

56. Id.

57. Id. at 82.

58. San Francisco Alta California, Dec. 18, 1883. 
hand, Hoffman, Sawyer, and Sabine were accused of "playing with" and creating "loopholes" in the Restriction Act. ${ }^{59}$ Even worse culprits, according to the press, were the Chinese and their attorneys. With both the help of counsel and systematic lying, it was believed that the Chinese were succeeding in undermining the Restriction Act. As early as December 1883, the San Francisco Alta California renamed that law the "Chinese Evasion Act" and "An Act to perfect the art of lying among the Chinese and their white auxiliaries." 60

In the face as such criticism, Hoffman publicly responded in the case of In Re Tung Yeong (1884). ${ }^{61}$ As with most of the handful of his written opinions in habeas corpus cases, the petitioner at hand figured largely as the means to discuss the broader issues of the writ litigation. Due to the pressure of hundreds of cases, most of Hoffman's writ decisions lacked written opinions. When an opinion was written, it served more as a commentary on the state of writ litigation than a recitation of the reasons for decision in the particular case. As such, Hoffman announced the discharge of Tung Yeong, citing evidence "beyond a rational doubt," establishing him as a prior resident who had left the United States before return certificates were available. ${ }^{62}$ Hoffman spent the bulk of the opinion vindicating his collective decisions in the habeas corpus cases, which "though much criticised," he felt had not been "thoroughly understood." 63

In the Tung Yeong opinion, Hoffman summarized the three types of Chinese habeas corpus applications: laborers claiming prior residence, applicants seeking to enter on Canton certificates, and children rejoining their parents in San Francisco. Only the first two categories caused problems for Hoffman. With respect to prior residents lacking return certificates, Hoffman defended his decision in In Re Chin Ah On (1883), to allow them to establish their right to enter as provided by the treaty. In the vast majority of such cases, he asserted that Chinese petitioners had met their burden of proof by documentary evidence or by corroboration of testimony sufficient "to satisfy any candid and unbiased mind." 64 Admitting that he may have been deceived in some instances, Hoffman believed the number to be small, "considering that in no case has a person been allowed to land on the plea of previous residence on unsupported Chinese oral testimony." 65

With respect to Canton certificates, the situation, Hoffman conceded, was "exceedingly embarrassing to the court" and had "almost insuperable

59. Id., Jan. 17, 1884.

60. Id., Dec. 18, 1883. See also, id. Jan. 5 and 17, and Feb. 12, 1884.

61. In re Tung Yeong, 19 F. 184 (D.C.D.Ca. 1884).

62. Id. at 190-19I.

63. Id. at 185 .

64. Id. at 187.

65. Id. 
difficulties." 66 The principal difficulty lay in the fact that whatever doubts Hoffman had about the reliability of the certificates, they constituted, under the Act, prima facie evidence of a right to land. Moreover, as the treaty only expressly excluded laborers, Hoffman held "that the inquiry was not so much whether the person was a merchant, as whether he was a 'laborer,' and that that inquiry should relate not to his occupation or status in China, but to the occupation in which he was to be engaged in this country; as the intention and object of the law was to protect our own laborers from the competition and rivalry of Chinese laborers here." ${ }^{67}$ Since the burden of proof thus rested with the United States attorney to rebut the apparent merchant status of immigrants, attorneys for Chinese petitioners routinely introduced Canton certificates into evidence and then rested their case. Despite the considerable latitude accorded the United States attorney in questioning petitioners and Hoffman's own cross-examination, he believed an undetermined number of Chinese had been wrongfully landed simply because the government's attorney had not met his burden of proof.

Lamenting the potential frauds practiced upon his court, Hoffman failed to see how they could have been prevented by "any court honestly and fearlessly discharging its duty under the law and evidence." ${ }^{68} \mathrm{Re}$ sponding to those who resented the presence of Chinese in his court, Hoffman gave a short lecture on constitutional law.

By the constitution and laws of the United States, Chinese persons in common with all others have the right 'to the equal protection of the laws' and this includes the right 'to give evidence' in courts. A Chinese person is therefore a competent witness. To reject his testimony when consistent with itself, and wholly uncontradicted by other proofs, on the sole ground that he is a Chinese person, would be an evasion, or rather violation, of the constitution and law, which every one who sets a just value upon the uprightness and independence of the judiciary would deeply deplore. ${ }^{69}$

Thus, when the preponderance of proof rested with a Chinese petitioner, Hoffman felt compelled to discharge him despite his reservations. Nonetheless, Hoffman sought to deflect criticism by citing statistics from the customs house, indicating that since the Restriction Act, five times more Chinese had left than had arrived in San Francisco. What Hoffman never fully appreciated, however, was that such statistics had far less impact on the public mind than did the reports of the hundreds of Chinese he had discharged in the district court.

66. Id.

67. Id. at 188.

68. Id. at 190 .

69. Id. 
The ambiguities and the judicial interpretation of the first Restriction Act that led Hoffman to decide as he did prompted amendments to the Act that were passed into law on July $5,1884 .^{70}$ The principal changes in the second Restriction Act made return certificates the only permissible evidence for a laborer to establish a right of reentry. Non-laborers could enter the country only if they produced Canton certificates that had been verified by American consuls in China. While such Canton certificates were to be the only permissible evidence available to non-laborers seeking entry, they still could be challenged by customs house officials. ${ }^{71}$ While the new Act generally made it more difficult for Chinese to establish their right to enter the United States, it did not prove to be a panacea for the anti-Chinese movement. Hoffman and Sawyer continued to interpret the second Act in the light of the treaty rights accorded the Chinese, and both judges refused to construe the Act in ways that would accomplish exclusion, as the more pragmatic Field proved willing to do.

In their earliest opinions interpreting the new Act, both Sawyer and Hoffman acknowledged and implemented its tighter requirements, although each reiterated the seemingly obvious point that the $1884 \mathrm{Act}$ (as the $1882 \mathrm{Act}$ ) was not intended to work retroactively. In other words, they insisted that return certificates, which were unavailable to Chinese at the time they left San Francisco, should not be made a condition of their reentry. Hoffman refused to accept such an interpretation of the $1884 \mathrm{Act}$, because doing so meant accusing Congress of "gross disingenousness, and of utter disregard of a treaty stipulation, to the observance of which the national honor was pledged." 72

Given the mood following the passage of the Act of 1884, Hoffman also felt obliged to defend his past record of allowing the Chinese to seek writs of habeas corpus.

That any human being claiming to be unlawfully restrained of his liberty has a right to demand a judicial investigation into the lawfulness of his imprisonment is not questioned by any one who knows by what constitutional and legal methods the right of liberty is secured and enforced by at least all English-speaking peoples. ${ }^{73}$

Hoffman's defense of the rights of the Chinese under the treaty and to writs of habeas corpus hardly altered his low opinion of the Chinese generally. He spoke of their "unscrupulous mendacity" and "fertile ingenuity" as well as "the endless gamut of deceptions which have in so many instances

70. 23 Stat. 115.

71. Id. at sections $4 \& 6$.

72. In re Shong Toon, 21 F. 386, 389 (D.C.D.Ca. 1884); see also In re Ah Quan, 21 F. 182 (C.C.D.Ca. 1884).

73. In re Chin Ah Sooey, 21 F. 393 (D.C.D.Ca. 1884). 
wearied and disgusted the court." 74 Despite misgivings, Hoffman felt obliged to render decisions that suggested to the public that he was "engaged in a persistent effort to defeat on technical grounds the operation of the [Restriction] law." 75

Field returned to the West Coast in September 1884, determined to take a harder line with the Chinese and correct his misguided colleagues. Presiding over a judicial panel composed of Sawyer, Hoffman, and Sabine, Field's position as circuit justice made his opinion controlling, even in the face of dissent by his three judicial colleagues. In several early opinions, Field insisted upon strictly enforcing the requirements of the 1884 Act. Moreover, Field resolved a pressing practical question by deciding that the vessels that brought Chinese subsequently remanded by the courts were responsible for returning them to China. ${ }^{76}$

The Alta California reacted by suggesting that California had been wrong about Field. Although he had previously struck down anti-Chinese laws as violating the Burlingame Treaty, Field had, according to the newspaper, suggested the enactment of the first Restriction Act. In addition, by his most recent opinions, Field closed loopholes through which the Chinese had been getting into the country, and swept away "the false and unreliable parol [oral] testimony of the Chinese." 77 Field's zeal in stopping Chinese immigration, however, brought him to an extreme position from which Sawyer, Hoffman, and Sabine dissented, even as the press applauded Field. The most important test case during Field's September visit raised a question that had already been settled by the Ninth Circuit in accordance with the spirit of interpretation, that Field himself had endorsed in 1882.

The habeas corpus petition of Chew Heong in 1884 became the test case that drove a wedge between Field and his judicial colleagues in the West. ${ }^{78}$ Chew Heong was a Chinese laborer resident in the United States at the time of the 1880 treaty with China, who left California before the 1882 Restriction Act went into effect. As such, he departed before the availability of return certificates. Chew Heong thus sought to establish his right of reentry in 1884 based on his prior residence. The estimates of the number of Chinese who had similarly left California before any return certificates existed varied from 12,000 to $15,000 .^{79}$

Field revealed his determination to exclude the potential return of so many Chinese in a colloquy with one of Chew Heong's attorneys, Thomas D. Riordan, during oral argument before the circuit court. Riordan pointed

74. In re Shong Toon, 21 F. 386, 392 (D.C.D.Ca. 1884).

75. In re Chin Ah Sooey, 21 F. 393, 395 (D.C.D.Ca. 1884).

76. In re Ah Kee, 21 F. 701 (C.C.D.Ca. 1884); In re Ah Moy, 21 F. 785 (C.C.D.Ca. 1884); In re Kew Ock, 21 F. 789 (C.C.D.Ca. 1884).

77. San Francisco Alta California, September 25, 1884.

78. In re Chew Heong, 21 F. 791 (C.C.D.Ca. 1884).

79. San Francisco Alta California, Sept. 27, 1884; Coolidge, supra note 11, at 498. 
out that the judges now sitting with Field (Sawyer, Hoffman, and Sabine) had unanimously held that return certificates in such cases as Chew Heong's were not strictly required. The Alta California reported the following exchange between Field and Riordan:

Justice Field: The law [Restriction Act of 1884] is perfectly plain. It says that the certificate shall be the only evidence. How many Chinamen will try to come in the same way?

Mr. Riordan: About 12,000.

Justice Field: And what shall the Courts do with them? Can it give each one of them a separate trial? Can it let each of them produce evidence of former residence? No; it was because the Courts were overcrowded that the second Act was passed. It was to relieve that pressure. Besides, Congress never supposed that Chinamen intended to go back to China and stay several years. If they do not come back at once they should not be allowed to come at all. We can't have them going away and staying as long as they want to.

Mr. Riordan: Then I suppose, your Honor, it is no use arguing the case further.

Justice Field: Not in the least. My mind is made up on the matter. If there is any special hardship, there are other ways of remedying it. Bring the case to the notice of the Chinese Minister at Washington, let him present it to the Secretary of State, with the request that our Minister to China look into the matter and report on it. Or, if you would prefer, appeal the case to the Supreme Court of the United States and have it settled there. ${ }^{80}$

The reaction of the other federal judges sitting with Field was unfortunately not recorded by the Alta California reporter. It can safely be assumed, however, that they were not smiling.

In rejecting the earlier opinions of his fellow judges, Field held that the 1882 Act had intended by its terms to allow only those Chinese laborers in the United States at the time the Act was passed to leave and still return. Those Chinese who left the country before the Act took effect were to be excluded; and without a return certificate, no oral evidence could be received to establish reentry. By implication, Field suggested that despite their good intentions, Sawyer, Hoffman, and Sabine had, in effect, evaded or misconstrued the Restriction Act of 1882 . Field clearly understood the popular mood of Californians toward their federal judges and the Chinese:

Oftentimes, indeed, there is a sense of impatience in the public mind with judicial officers for not announcing the law to be what the community at the time wishes it should be. And nowhere has this feeling

80. San Francisco Alta California, Sept. 27, 1884. 
been more manifested than in California, and on no subject with more intensity than that which touches the immigration of Chinese laborers. ${ }^{81}$

Field's opinion could not have been better calculated to appease what he had called "impatience in the public mind." 82

On behalf of Hoffman and Sabine, Sawyer filed a lengthy dissent in Chew Heong, in which he examined the Restriction Acts in light of the treaty with China. Sawyer saw no foundation for the argument that prior Chinese residents be required to produce certificates which they could not have obtained. Moreover, the dissenters disagreed with Field's implication that Chinese laborers who left in good faith with the 1882-type certificates would be required to produce 1884-type certificates. Primarily, the dissenters argued that Field's decision which excluded Chinese laborers came at too high a price, namely, "the plighted faith of the nation." ${ }^{33}$ Sawyer argued that the previous decisions of the Ninth Circuit had not only observed the treaty, but had been accompanied by a substantial decrease in the number of Chinese in California. As it was, Riordan took Field's advice and appealed the decision to the Supreme Court, where Field's decision was reversed for substantially the same reasons as those given by the dissenters below. ${ }^{84}$ Field filed a particularly shrill dissent attacking his

81. In re Chew Heong, 21 F. 791, 793 (C.C.D.Ca. 1884).

82. See, e.g., San Francisco Alta California. Sept. 27, 1884.

Indeed, Field's earlier Chinese decisions had played a significant role in frustrating his political ambitions, and public reaction to them may well account for his turnabout in the Chew Heong case.

Having long harbored presidential aspirations, Field's candidacy in 1880 suffered from the failure of Californian support-due in part to a disenchantment with Field over the Chinese cases he had decided even before the passage of the first Restriction Act. See C.B. Swisher, Stephen J. Field, Craftsman of the Law 283 \& 288 (1963 reprint of 1930 ed.). Four years later, Field explicitly blamed his failure to receive the nomination of the Democratic party in 1884 on the fact that his own party in California had repudiated him. See Stephen J. Field to John N. Pomeroy, July 28, 1884 (Stephen J. Field Papers, Bancroft Library).

Although rendered two months after he lost his bid for the 1884 presidency, Field's widely praised opinion in Chew Heong may have been influenced by his political ambitions. Field's claims that his political quest was over with the defeat in 1884 cannot be taken at face value, because similar protestations after his unsuccessful bid for the presidency in 1880 had not stopped him from seeking that office in 1884. See Swisher, supra at 298.

In any event, some such considerations must have motivated Field, because his decision in Chew Heong could scarcely be reconciled with his interpretation of the Restriction Act two years earlier.

83. In re Chew Heong, 2I F. 791,808 (C.C.D.Ca. 1884).

84. Chew Heong v United States, 112 U.S. 536 (1884). 
circuit as well as Supreme Court colleagues, claiming they had rendered the 1884 Act "nugatory." 85

When news of the Supreme Court's reversal reached California, the three original dissenters felt, in turn, vindicated. In a letter to the federal district judge in Oregon headed "Confidential-Destroy," Sawyer confessed that,

[I]t is some consolation, after all the lying, abuse, threatening of impeachment etc. as to our construction of the Chinese restriction act, and the grand glorification of brother Field for coming out here and so easily, promptly and thoroughly sitting down on us and setting us right on that subject to find that we are not so widely out of our senses after all. ${ }^{86}$

Moreover, Sawyer mentioned a commendation he had received from a stranger in Wisconsin, for upholding the rights of Chinese "with courage and energy in opposition to a strong current of popular clamor," and predicted that "time will bring us out about right."

Despite the vindication of their interpretation and approach to the 1882 and 1884 Acts, the three dissenting judges would continue to be plagued by federal officials straining to exclude the Chinese. In September 1884, John $S$. Hager became the new collector for the port of San Francisco. Senator Stewart of Oregon remembered that no one exceeded Hager as a "more zealous opponent" of Chinese immigration. As "one of the first who discovered the Chinese evil, . . . his consistency in opposition to it cannot be questioned." 88 In an interview shortly after his appointment, Hager declared that he would not tolerate any further "interference" by the federal judges and asserted that the Chinese had no right to come before their courts. ${ }^{89}$ While Hager's stand met with public approval, his efforts to bypass the courts were quickly challenged by Judge Hoffman.

In October 1885, a petition of habeas corpus was sought from Hoffman's court on behalf of two Chinese who were denied entry because they had no certificates, even though they claimed to be California residents returning from a trip to China. ${ }^{90}$ Under pressure from Hager, United States attorney Hilborn challenged the issuance of a writ. Hilborn argued that since the collector had passed judgment on matters of law and fact, the same were res judicata, and thus the district court was without jurisdiction.

85. Id. at 561 .

86. Lorenzo Sawyer to Matthew P. Deady, Dec. 22, 1884 (Deady Papers, OHS).

87. Id.

88. Cong. Record, 50th Cong., 1st Sess., 7304.

89. San Francisco Alta California, Sept. 23, 1885.

90. In re Jung Ah Lung \& In re Jung Ah Hon, 25 F. 141 (D.C.D.Ca. 1885). 
Hoffman expressed outrage at the presumptuousness of the government's argument. "The petitioner is a free man, under our flag, and within the protection of our laws," and Hoffman found his denial of the right to land a clear instance of a restriction of liberty. ${ }^{91} \mathrm{He}$ reiterated the importance of the writ to "English-speaking peoples" as "the most sacred" document of "personal freedom" and its availability to everyone, "no matter what his race or color." 92 This ringing assertion of the rights due the petitioners, however, did not stop Hoffman from complaining about "the unspeakable Chinese" only two months later. ${ }^{93}$

Hoffman also rejected the argument that the Chinese might not be entitled, in his court, to a full review of the facts surrounding their detention as an "extraordinary pretention" that sought to make a mere executive decision "final and conclusive." 94 If Chinese were entitled to writs of habeas corpus, then "to require the court in its investigations to be governed by the decision of an executive officer acting under instructions from the head of the department at Washington, would be an anomaly wholly without precedent, if not flagrant absurdity." 95 Upon appeal, Hoffman's decision was upheld by the Supreme Court, giving additional force to Hoffman's conviction, as he expressed it to a newspaper reporter in 1888 , that the right of Chinese to land "must be decided by the Courts, and by the Courts alone."96

Judicial control over Chinese immigration brought additional censure upon the federal courts, because they heard habeas corpus petitions without juries. Assistant United States attorney Carrol Cook made a pointed reference to that fact in 1885 , during the first criminal prosecution in the northern district of a Chinese defendant accused of falsifying a return certificate. In his opening remarks to the jury, Cook asserted that habeas corpus cases:

have been going on for the last two or three years until the Court, Counsel, and Spectators have become disgusted with the sickening prevarication and perjury that has prevailed in these cases since their inception. Now for the first time we present this kind of testimony to a Jury of Citizens of the State of California. ${ }^{97}$

The implication was, of course, that Hoffman had at the very least been repeatedly duped in the writ cases. Cook's general description

91. Id. at 142 .

92. Id. at 143 .

93. Ogden Hoffman to Matthew P. Deady, Dec. 12, 1885 (Deady Papers, OHS).

94. In re Jung Ah Lung \& In re Jung Ah Hon, 25 F. 14I, 142 (D.C.D.Ca. 1885).

95. Id. at 143.

96. United States v. Jung Ah Lung, 124 U.S. 62l (1888); San Francisco Alta California, March 23, 1888.

97. United States v. Choi Ah Jow, Criminal Casefiles, 2nd Series, Bill of Exceptions, 9 [2021]. 
of the habeas corpus litigation strongly suggested that Hoffman was largely to blame for continued Chinese immigration.

When a Chinaman is refused landing on the ship he attempts to gain an entrance in any way that is possible. He secures sometimes the ablest and most learned counsel and in other cases he secures those who would stoop to anything. He is represented by all the ingenuity that is possible. Every kind of excuse is made, every loop-hole to tear assunder this law [Restriction Act of 1884], and as I said before, what he cannot swear to is not worth swearing to as a rule. ${ }^{98}$

Cook carried the point, for the jury found Choi Ah Jow guilty. Such hyperbole characterized the rhetoric of the federal officials who sought to stop the entry of Chinese into San Francisco, and their strict policies continued to flood the federal courts with habeas corpus cases even as the relative number of Chinese in the city declined. In May 1887, Sawyer complained that the "zealous customs house officers . . . reject these people [the Chinese] without rhyme or reason." 99 Sawyer and Hoffman continued to hear record numbers of writ cases, despite Hoffman's ill health during much of the time. By January 1888 , the Alta California, relying on customs house records, reported that after the restriction Acts had been in operation for almost five years, $87 \%$ of the almost 4,000 Chinese who sought writs of habeas corpus from the federal courts had been landed. ${ }^{100}$ Even though the customs house records also showed that between 1882 and 1887 Chinese departures had exceeded arrivals by more than 25,000 , the habeas corpus cases kept the federal judges before the public eye and subject to continuous criticism. $^{101}$

Little relief seemed imminent from what Sawyer called "an intolerable nuisance." 102 By 1888 , he complained that "we are buried out of sight in Chinese habeas corpus cases," and Hoffman was at a loss "to convince one who has never been in these Courts how great is the physical distress and mental strain caused by a day's conscientious attention to these Chinese cases." 103 After "weeks and months" of "torture to mind and body,"

98. Id.

99. Lorenzo Sawyer to Matthew P. Deady, May 25, 1887 (Deady Papers, OHS).

100. San Francisco Alta California, Jan. 25, 1888.

101. San Francisco's Collector John S. Hager reported that between August 1882 and the end of 1887, 36,989 Chinese had arrived, while 62,407 had departed. See U.S. Congress, Senate, LetTter of Collector J.S. Hager, Giving Statistics of the Number of Arrivals and Departures of Chinese at the Port of San Francisco, Sen. Misc. Doc. 90, 50th Cong., Ist Sess., 1887-1888.

102. Lorenzo Sawyer to Matthew P. Deady, May 25, 1887 (Deady Papers, OHS).

103. Lorenzo Sawyer to Matthew P. Deady, March 4, 1888 (Deady Papers, OHS); San Francisco Alta California, March 8, 1888. 
Hoffman had experienced bouts of illness from which Sawyer thought he might not be able to recover. ${ }^{104}$ While temporarily running the habeas corpus "mill" alone, Sawyer declared himself "utterly discouraged" because "the more I do, and the harder and faster I work the more villainously and vigorously I am abused." 105 Hoffman, as well, found that the unremitting prospect of Chinese cases filled him "with dismay and almost with despair," and his frustration spilled over into his written opinions. ${ }^{106}$ Hoffman eventually recovered, and relief finally appeared on the horizon, in the form of efforts to renegotiate the treaty with China. By May 1888, Sawyer anticipated a respite from the Chinese cases provided that "Congress won't upset the matter by bungling legislation" to put the treaty in effect. ${ }^{107}$

In the end, the reluctance of China to ratify the new treaty prompted the passage of the first Chinese exclusion law. ${ }^{108}$ Unlike the acts of 1882 and 1884 that were designed to enforce existing treaties, the 1888 Act's purpose was to exclude Chinese laborers for good. Non-laborers, such as merchants holding requisite certificates, were still allowed entry. A Chinese laborer already in the United States could only reenter after the passage of the Act if he had "a lawful wife, child, or parent in the United States or property therein of the value of one thousand dollars, or debts of like amount due him and pending settlement. ${ }^{109}$ In addition, return certificates, which were indispensable for entry, constituted the only evidence of a right of reentry, and were limited to one year. ${ }^{110}$ President Grover Cleveland signed the bill into law, and within twenty-four hours, the customs house officials and federal judges in San Francisco were notified by telegram that the Act was to be enforced at once. ${ }^{111}$

The importance of the Act to both sides resulted in a test case within two weeks of the bill becoming law. ${ }^{112}$ Immediate enforcement of the Act potentially affected over thirty thousand Chinese who had left China with pre-1888 return certificates, but who had not yet returned to California. ${ }^{113}$

104. San Francisco Alta California, March 8, 1888.

105. Lorenzo Sawyer to Matthew P. Deady, March 4, 1888 (Deady Papers, OHS).

106. Ogden Hoffman to Charles N. Felton, Jan. 1888, in Cong. ReCord, 50th Cong., ist Sess., 6569.

107. Lorenzo Sawyer to Matthew P. Deady, May 23, 1888 (Deady Papers, OHS).

108. Act of September 13, 1888, 25 Stat. 476.

109. Id. at section 6 .

110. Id. at section 7 .

111. San Francisco Alta California, Oct. 3, 1888; San Francisco Chronicle, Oct. 3, 1888.

112. In re Chae Chan Ping, 36 F. 43 ! (C.C.N.D.Ca. 1888). This case was to become known as the Chinese Exclusion Case.

113. San Francisco Alta California, Oct. 3 and 14, 1888. 
Chae Chan Ping was one such laborer who had resided in California from 1875 until 1887 when he left for China with a return certificate. En route to San Francisco from Hong Kong when the 1888 Act became law, Chae Chan Ping arrived in the city on October 7 , and was refused permission to land on the grounds that the 1888 Act had annulled the return certificate. Both Sawyer and Hoffman formed the circuit court that heard arguments in the case, and on October 15, Judge Sawyer sustained the Act. Sawyer held that since both treaties and federal laws were "supreme," in any unavoidable conflict, (such as that presented by the $1888 \mathrm{Act}$ ), the earlier had to give way to the later. ${ }^{114}$ Upon appeal to the Supreme Court, Justice Field delivered the unanimous opinion of the court, and sustained the Act in very broad terms. ${ }^{115}$

While the affirmation of Sawyer's decision ended any challenge to the Act itself, it did not mark, as many thought, an effective end to Chinese immigration and the use of the federal courts by the Chinese to establish their right of entry. The anti-Chinese movement might have observed that Sawyer went out of his way to explain that the decision he and Hoffman reached did not represent a capitulation to popular prejudice. ${ }^{116}$ Indeed, Sawyer wrote to Judge Deady in Oregon about the Chae Chan Ping decision and confided that he and Hoffman felt compelled by the terms of the Act to decide as they did. ${ }^{117}$ Moreover, in the same letter Sawyer announced that he and Hoffman had rejected an overly narrow interpretation of the 1888 Act by the collector. ${ }^{118}$ Hager had refused to land Chinese laborers traveling from Seattle to San Francisco via Victoria, claiming they had departed from the United States by entering and then leaving British waters. It seemed to Sawyer "as though the Executive departments are determined to make our government as odious to the rest of the world as possible." 119

Far from cutting off access to the federal courts, the 1888 Act resulted in additional habeas corpus cases well after Hoffman's death in $1891 .^{120}$ In addition to refusing a literal interpretation of the 1888 Act, Sawyer and Hoffman refused to automatically remand those Chinese out on bail and awaiting a decision at the time the Act was passed. Although the Supreme Court later approved such a retroactive application of the Act in mid-1891,

114. In re Chae Chan Ping, 36 F. 431 (C.C.N.D.Ca. 1888).

115. Chae Chan Ping v. United States, 130 U.S. 581 (1889).

116. In re Chae Chan Ping, 36 F. 431, $436-37$ (C.C.N.D.Ca. 1888).

117. Lorenzo Sawyer to Matthew P. Deady, Oct. 18, 1888 (Deady Papers, OHS).

118. In re Tong Wah Sick, 36 F. 440 (C.C.N.D.Ca. 1888); see also In re Jack Sen, 36 F. 441 (C.C.N.D. Ca. 1888).

119. Lorenzo Sawyer to Matthew P. Deady, Oct. 18, 1888 (Deady Papers, OHS).

120. See Admiralty (Private) Dockets, vols. 14-18 (1890-1906). 
by that time the backlog of cases had been disposed of under the Acts of 1882 and $1884 .^{121}$ Moreover, many of those Chinese arriving in San Francisco after October 1888 quickly disposed of their now useless return certificates, and sought entry on such grounds as being "merchants" or "American born citizens." ${ }^{22}$ While the newspapers decried that "certain class of lawyers" abetted the Chinese in "the habeas corpus business," the federal courts continued to land far more petitioners than they remanded. ${ }^{123}$ For example, in Hoffman's court between October 1, 1888, and December 1,1890 , a total of 1,401 Chinese habeas corpus cases were filed. Of the 620 cases decided by the end of that period, 533 or $86 \%$ ended in the discharge of the petitioner, while only 87 or $14 \%$ of the Chinese were remanded. ${ }^{124}$

The efforts of the Chinese to use the federal courts to ameliorate the effects of exclusion were ultimately a losing battle, especially after the deaths of both Hoffman and Sawyer in 1891. ${ }^{125}$ Those two judges had experienced the brunt of the criticism for their decisions. Obviously stung by such disapproval, they nonetheless felt vindicated by the Supreme Court's affirmations. Even in the midst of rendering their popular decision upholding the 1888 Act, the judges exhibited the defensive pride that characterized their Chinese habeas corpus cases. Sawyer summed up those decisions in his opinion in the Chae Chan Ping case, "We have, heretofore, found it our duty, however unpleasant at times, to maintain, fearlessly and steadily the rights of Chinese laborers under our treaties with China, and the acts of Congress passed to carry them out." 126

Hoffman's experience as a trial judge, rather than his attitudes towards treaties, procedure, or judicial independence, probably proved more determinative of the fact that thousands of Chinese that walked out of his courtroom. Unlike most critics of Chinese immigration, Hoffman's judgeship forced him to deal with the Chinese on a personal, day-to-day basis. Despite his generalized bias towards the Chinese, in his court he faced not "the Chinese," but individual Chinese petitioners. The thousands of separate hearings individualized "the Chinese," forcing Hoffman to see and hear them as human beings with distinct explanations and histories that had to be dealt with on a case-by-case basis. Unlike Field, who only heard test cases in which the Chinese petitioner at hand was largely incidental and symbolic of many others similarly situated, Hoffman and Sawyer ulti-

121. Wan Shing v. United States, 140 U.S. 424 (1891).

122. See San Francisco Alta California, Oct. 20, 24, and Nov. 26, 1888; San Francisco Chronicle, Oct. 21 \& Nov. 13, 1888.

123. San Francisco Alta California, Oct. 20, 1888.

124. Joint Select Committee on Immigration and Naturalization, H.R. Rep., 4048: 2: 412 , 51st Cong., 2nd Sess., 1890-1891.

125. See Janisch, supra note 1, at 903-1087.

126. In re Chae Chan Ping, 36 F. 431, 436 (C.C.N.D.Ca. 1888). 
mately could not maintain Field's detachment. Hoffman, for instance, expressed his personal delight at being able to avoid separating Chinese children from their parents. Likewise, both he and Sawyer repeatedly spoke of the admirable and respectable qualities of individual Chinese, even as they decried their limitations as a race.

That so many Chinese petitioners succeeded in convincing Hoffman and Sawyer that they were legitimately entitled to land underscores the gap between the judges' racial rhetoric and judicial action. Few critics of continued Chinese immigration could explain why a people, believed to be so notoriously untrustworthy, succeeded time and time again in convincing Hoffman and Sawyer to decide in their favor. The paradox owes much to the fact that unlike the customs house officials who were able and certainly willing to implement a bureaucratic procedure that systematically excluded the Chinese, Hoffman's conduct of habeas corpus proceedings presented too many opportunities for individual expression and argument. While the sheer number and similarity of many of these cases "bureaucratized" the process in some respects-as Hoffman's and Sawyer's factory-like nickname for their courts suggests - they never became automatic decisions with predictable results. Having asserted their right to such hearings, it followed for Hoffman that each Chinese petitioner could present any evidence, testimony, or argument in favor of establishing his liberty. The nature of the judicial process itself thus forced a case-by-case appraisal of the Chinese petitioners, which resulted in decisions affecting one person at a time rather than an entire race or class.

In contrast, Stephen Field could speak in sweeping terms about how to deal with "the Chinese problem." His perspective, like that of the collector, did not include the need to look at the Chinese coming before the federal courts as individuals. The collector was quite willing to make an executive decision that would unilaterally affect Chinese people. As a trial judge, Hoffman found himself enmeshed in a far more complicated process. His sense of the importance of maintaining treaty rights and due process in his court resulted in decisions that further estranged him from the forces that sought to end Chinese immigration, even though he agreed with them in principle. Despite his strong desire to be rid of the habeas corpus mill, Hoffman could not avoid that obligation without repudiating his concept of judicial review, duty, and the common law tradition. This Hoffman was not prepared to do. 